\title{
膀胼癭による持続潅流式経尿道的前立腺切除術
}

\author{
新潟市民病院泌尿器科 \\ 大沢哲 雄 中 村章
}

\section{TRANSURETHRAL PROSTATIC RESECTION WITH SUPRAPUBIC TROCAR TECHNIQUE}

\author{
Tetsuo Osawa and Sho Nakamura \\ Division of Urology, Niigata Shimin Hospital, Niigata, Japan
}

The use of a suprapubic trocar in transurethral prostatic resection was evaluated and compared to the conventional filling and emptying technique. Fifty transurethral prostatic resections with suprapubic trocar and 19 resections by conventional technique were performed from Oct. 1984 to Dec. 1985. The operating time (minutes per gm of resected tissue) of the TURP with trocar was $2.5 \mathrm{~min} / \mathrm{gm}$, which was significantly shorter than that of the conventional TURP $(3.2 \mathrm{~min} / \mathrm{gm})$. The loss of blood during TURP was slightly larger in the group operated on with trocar technique when over $30 \mathrm{gm}$ tissue was resected. The concentration of serum sodium just after operation, that indicated the absorption of the irrigating fluid, was lower in the group with conventional technique, especially when over $30 \mathrm{gm}$ tissue was resected. The bladder pressure during suprapubic trocar technique did not exceed $10 \mathrm{cmH}_{2} \mathrm{O}\left(0 \sim 8 \mathrm{cmH}_{2} \mathrm{O}\right)$, but the pressure at conventional technique was between 0 and $81 \mathrm{cmH}_{2} \mathrm{O}$.

We recommend the suprapubic trocar technique in TURP, since it saves the time of resection and it holds the bladder pressure under the pelvic venous pressure, there by the amount of absorbed fluid is minimized. And the technique facilitates the operation, because we can keep the view clearly and uninterruptedly

要旨：Trocar を用いた恥骨上膀胱㾇による持続潅流式経尿道的前立腺切除（TURP）を working element を抜いて膀脱内潅流液を排液する従来の TURP と比較検討した。対象は1984年10月から1985年12 月までに行われた持続潅流式 TURP 50例と従来の TURP の19例とした。

単位重量当たりの手術時間は持続潅流式 TURP で2.5分/g, 従来の TURP で3.2分/gであり, 持続潅 流式 TURP の方が有意に短縮された。切除重量 $30 \mathrm{~g}$ 以上では, 持続潅流式 TURP が従来の TURP に比 し, 出血量が多い傾向にあった。 術後の血清 $\mathrm{Na}$ 值の低下は, 従来の TURP の方が著明で, 潅流液吸収 が持続潅流式 TURP に比べ多いと考兄られ, この傾向は, 切除重量 $30 \mathrm{~g}$ 以上の比較的大きい腺腫の場合 でより一層明らかであった。 術中膀胱内圧は, 持続潅流式 TURP は $0 \sim 8 \mathrm{cmH}_{2} \mathrm{O}$ と低く保たれたが, 従 来の TURP の場合は0 $81 \mathrm{cmH}_{2} \mathrm{O}$ となった.

以上より, 膀胱瘦による持続潅流式 TURPは, 大きな腺腫の場合には, 従来の TURP に比べ出血量 が多い傾向にあるが，手術時間が短縮され，膀胼内圧を骨盤内静脈圧より低く保つことができるため, 潅流液吸収が少ないなどの優れた利点をもち，かつ視野が明瞭で，視野を見失らことなく連続的に手術 を行らことができるなどの点から，広く勧められるべき方法と考兄られる。

\section{緒百}

前立腺肥大症に対する手術は, 経尿道的前立腺切除 術（TURP）が主流となっている1). しかしTURPの 対象患者が高齢者であることから，できるだけ手術侵 襲を少なくする必要がある。そこで, return flow resectoscope (Iglesias technique) ${ }^{2)}$, 恥骨上膀胱瘦 による持続潅流式 TURP などがとりあげられた。こ
れらの方法は膀胱内圧が低く保たれるので, 前立腺床 からの潅流液の吸収が少ないと考劣られ，また潅流液 排除の操作が不要なことから良好な視野を持続的に確 保できるため, 手術時間の短縮をもたらすものと思わ れる。

われわれは，1984年末より膀胱瘻による持続潅流式 TURPを行っている. 膀脱瘦造設に用いる Trocar と 
図 1 膀胼瘻用穿刺セット（Wolf 社）

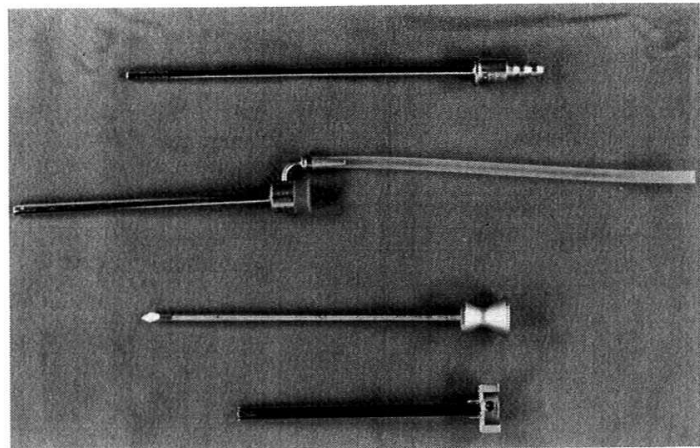

しては, 種々のものが報告されているが3) 6), 穿刺が容 易で, Trocar 先端に吸着する切除片を簡単に除去で きる Reuter 式 Trocar ${ }^{7}$ (図 1) 使用している。既に 多数例に行っており，本法が優れた方法であることを 実感しているが，今回本法と排液操作を要する従来の 方法とを比較, 検討した。

\section{対象と方法}

1984年10月から1985年12月に行われた TURPのら ち，今回の検討に必要なデータを測定していたものは 69例であった，膀脱㾇による持続潅流式 TURP が50 例で平均年龄は 72.4 歳(52 90歳), 従来の方法による TURP が19例で平均年齢は73.4歳（61８5歳）であっ た。麻酔は原則として硬膜外麻酔が行われ，術前およ び術中の輸液は乳酸リンダル液（ラクテック®）とし た。

膀胱瘦の造設は，先ず切除鏡にて膀胱内を観察した 後, 膀胱を潅流液で充満させ, 恥骨結合より約 $2 \mathrm{~cm}$ 頭 側に皮膚小切開を加光，16または17.5F Trocar(Wolf 社）を膀胱に刺入した。 Trocarょりの吸引 tube は吸 引ビンに接続して，弱い陰圧にしておいた。 サイフォ ン効果のみでも可能であるが, 時に気泡が tube 内に混 入して排液流出が不良となることもあり，ある程度の 陰圧をかけた方がよい，その後は通常の TURPを行 らが, 切除片で Trocar の吸引口が詰まり, 膀胼内圧が 上昇すると, Trocar 側枝の水位上昇がみられるので, その前に時々Trocar の内筒を数回上下させ，切除片 を Trocar 吸引ロ上り除くようにすれば, Trocar 閉塞 の問題はほとんど無い。

潅流液はウリガール液®を10倍希釈して使用し, 潅 流圧は50 80 $\mathrm{mmH}_{2} \mathrm{O}$ とした. TURP 終了後, Trocar 刺入部に12〜14Fのバルーンカテーテル（Foley）を插 入した。これは原則として術翌日に抜去した。
各症例につき，次の項目を測定した。1）手術時間括 よび切除重量：手術時間は first bite から, TURP 終 了後バルーンカテーテルを尿道に留置するまでの時間 とした，2）検血（RBC，Ht，Hb）；術前，TURP 終 了時, 手術翌日, 拉よび 1 週間後に測定し，検血比を 計算した。検血比は，術前検血值に対する術後の検血 值の比 (\%) を各項目 (RBC, Ht, Hb) について計算 し，これを平均したものである。ただし輸血症例では， 輸血以降の測定値は採用しなかった。3）血清 $\mathrm{Na}$ 值； 検血と同時に測定し, 検血比と同様にして, 術前 $\mathrm{Na}$ 值 に対する術後の $\mathrm{Na}$ 值の比(\%)を $\mathrm{Na}$ 比として計算し た.4）膀脱内圧測定； Trocar 側枝を Lewis 内圧計に 接続して膀胱内圧を記録した。

なお，輸血症例の頻度及び循環不全の徴候を示した 症例の頻度を検討したが，輸血症例とは，術中ないし 術後12時間以内に輸血したものとした。循環不全症例 とは, 麻酔効果が安定したと思われる手術開始 10 分後 より, 術後回復室における間に, (1)血圧 $80 \mathrm{mmHg}$ 以下 となり，昇圧剂を用いたもの，(2)血圧 $80 \mathrm{mmHg}$ 以上で あっても, $100 \mathrm{mmHg}$ 以下となり, 血圧回復までに昇圧 剤を複数回用いたものとした。

\section{結 果}

1）手術時間と切除重量（表 1)。膀胱㾞による持続

表 1 膀胱瘦による持続灌流式 TURP (Trocar $(+))$ と 従来の TURP (Trocar ( - ) ) の比較

\begin{tabular}{|c|c|c|c|c|}
\hline & Trocar (+) & $\operatorname{Trocar}(-)$ & 統計的事項* \\
\hline 全例 & $\begin{array}{l}\text { 症 例 数 } \\
\text { 切除重量 }(\mathrm{g}) \\
\text { 手術時間 (分) } \\
\text { 分 } / \mathrm{g}\end{array}$ & $\begin{array}{c}50 \\
30.1 \pm 17.1 \\
63.7 \pm 25.4 \\
2.5 \pm 0.9\end{array}$ & \begin{tabular}{c|}
19 \\
$26.0 \pm 18.4$ \\
$75.9 \pm 27.5$ \\
$3.2 \pm 1.0$
\end{tabular} & $\begin{array}{l}\text { (等分散) } \\
\mathrm{p}<0.01\end{array}$ \\
\hline $\begin{array}{l}40 \mathrm{~g} \\
\text { 以上 }\end{array}$ & $\begin{array}{c}\text { 症 例 数 } \\
\text { 切除重量 }(\mathrm{g}) \\
\text { 手術時間 (分) } \\
\text { 分 } / \mathrm{g}\end{array}$ & $\begin{array}{c}15 \\
52.5 \pm 9.8 \\
92.3 \pm 17.1 \\
1.8 \pm 0.3\end{array}$ & $\begin{array}{c}3 \\
62.3 \pm 15.6 \\
121.7 \pm 21.0 \\
2.0 \pm 0.1\end{array}$ & （等分散） \\
\hline $\begin{array}{l}39 \mathrm{~g} \\
20 \mathrm{~g}\end{array}$ & $\begin{array}{l}\text { 症 例 数 } \\
\text { 切除重量 }(\mathrm{g}) \\
\text { 手術時間 (分) } \\
\text { 分 } / \mathrm{g}\end{array}$ & $\begin{array}{c}18 \\
26.9 \pm 5.6 \\
59.4 \pm 17.3 \\
2.2 \pm 0.4\end{array}$ & $\begin{array}{c}7 \\
27.3 \pm 5.3 \\
77.9 \pm 12.5 \\
2.9 \pm 0.5\end{array}$ & （等分散） \\
\hline $\begin{array}{l}20 \mathrm{~g} \\
\text { 未満 }\end{array}$ & $\begin{array}{l}\text { 症 例 数 } \\
\text { 切除重量 }(\mathrm{g}) \\
\text { 手術時間 (分) } \\
\text { 分 } / \mathrm{g}\end{array}$ & $\begin{array}{c}17 \\
13.7 \pm 4.2 \\
42.8 \pm 11.7 \\
3.3 \pm 1.0\end{array}$ & $\begin{array}{c}9 \\
12.8 \pm 4.4 \\
48.3 \pm 16.0 \\
3.9 \pm 0.9\end{array}$ & （等分散） \\
\hline
\end{tabular}

*切除重量の分布はF-test にて等分散を証明. 単位重量当り手術時間（分 $/ g$ ) の比較はt-testによった (N.S. = not significant) 
潅流式 TURP (以後 Trocar (+) とする) が行われた 50 症例の平均切除重量は $30.1 \mathrm{~g}(5 \sim 80 \mathrm{~g})$, 平均切除時 間63.7分（25１20分）, 単位重量当たりの平均手術時 間は, 2.5 分であった。一方, 従来の方法による TURP (以後 Trocar (一) とする) が行われた 19 症例の平均 切除重量は26.0g (8～80g), 平均手術時間75.9分 (35〜150分), 単位重量当たりの平均手術時間は 3.2 分/ $\mathrm{g}$ であった。この単位重量当たりの平均手術時間は, Trocar $(+)$ の方が有意 $(\mathrm{p}<0.01)$ に短縮された。

単位重量当たりの平均手術時間をさらに詳しく分析 すると, 切除重量が $20 \mathrm{~g}$ 以上 $40 \mathrm{~g}$ 未満の腺腫の場合, Trocar (+) で2.2分/g, Trocar (-) で2.9分/g と なり, 明らかな有意差がみられた。一方, $20 \mathrm{~g}$ 末満の比 較的小さな腺腫では, Trocar $(+) て ゙ 3.3$ 分/g, Trocar （一）で 3.9 分/g となり，有意の差はなかった。をた， 逆に $40 \mathrm{~g}$ 以上の大きな腺腫の場合は, Trocar $(+) て ゙$ 1.8 分 $/ \mathrm{g}, \operatorname{Trocar}(-)$ で 2.0 分 $/ \mathrm{g}$ となり, これも有意 差はなかった。

2) 術後の検血比および輸血例の頻度（図 2,3 , 表 $2)$ 。術後の検血比は, 術直後では Trocar $(+)$ 群で は87.0\%，Trocar (一) 群で $86.5 \%$ と両群では汪とん ど差がなく, 翌日の検血比もほぼ同様であった(図 2 ). 切除重量 $30 \mathrm{~g}$ 以上のものに限って比較してみると。術

図 2 TURP 後の検血比（全症例）

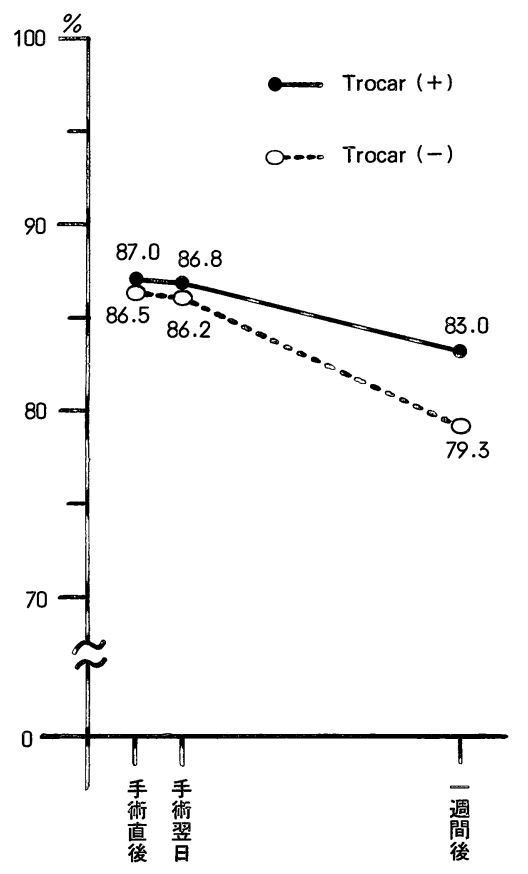

直後の検血比は $\operatorname{Trocar}(+)$ 群が80.1\%, Trocar $(-)$ 群が86.1\%となり，Trocar（+）の方の検出比が比較 的著明に低下していた（図 3 )。また輸血症例の頻度（表 2 ) は，全症例中 Trocar (+) 群で 7 例 (14.0\%), Trocar (一) 群で 1 例 (5.3\%) であったが, 切除重量 $30 \mathrm{~g}$ 以上の症例に限ると, Trocar (+) 群ではやはり 7 例 (30.4\%), Trocar (一) 群では輸血症例はなかっ た。このように，検血比拉よび輸血例の頻度から，特 に $30 \mathrm{~g}$ 以上を切除する場合は Trocar (+) の方が出血 量が多いと思われた。 また，術後 1 週間後の検血比を みると，術直後抢よび翌日の検血比より更に低下する 傾向を示した。特に $30 \mathrm{~g}$ 以上の, Trocar (一) 群で最 もこの傾向が著明であった（図 2,3 )。

図 3 TURP 後の検血比 ( $30 \mathrm{~g}$ 以上)

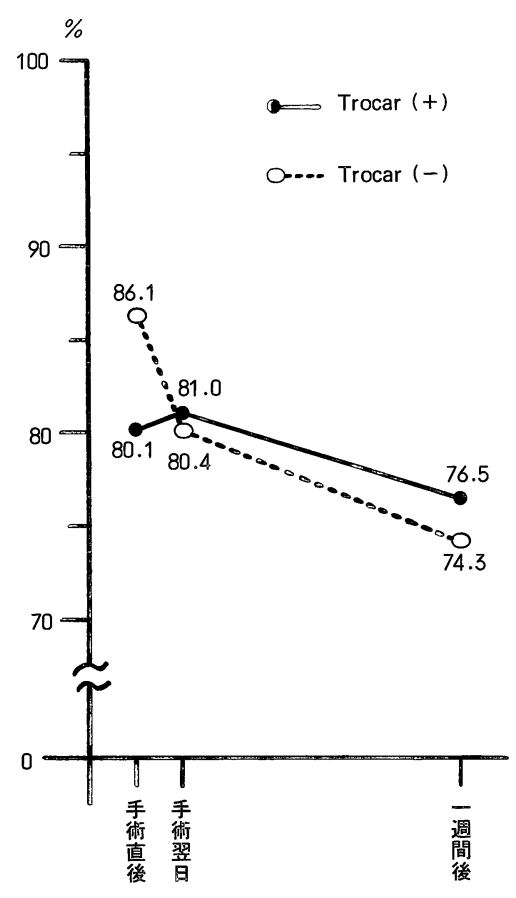

表 2 持続灌流式 TURP (Trocar (+)) と従来の TURP (Trocar (一)) の輸血頻度执よび循環不全発症頻度

\begin{tabular}{|c|c|c|c|c|}
\hline & Trocar $(+)$ & Trocar (-) & 有意差 ${ }^{3)}$ \\
\hline 輸 & $\begin{array}{l}\text { 全症例 }{ }^{1)} \\
>30 g^{2)}\end{array}$ & $\begin{array}{l}14.0 \%(7 \text { 例 }) \\
30.4 \% \text { ( 7例) }\end{array}$ & $\begin{array}{c}5.3 \% \text { ( } 1 \text { 例) } \\
0 \%\end{array}$ & $\begin{array}{l}\text { NS } \\
\text { NS }\end{array}$ \\
\hline 循環不全 & $\begin{array}{l}\text { 全症例 }{ }^{1)} \\
>30 \mathrm{~g}^{2}{ }^{2}\end{array}$ & $\begin{array}{l}22.0 \% \text { (11例) } \\
39.1 \% \text { ( 9例) }\end{array}$ & $\begin{array}{l}26.3 \% \text { ( } 5 \text { 例) } \\
83.3 \% \text { ( } 5 \text { 例) }\end{array}$ & $\begin{array}{l}\text { NS } \\
\text { NS }\end{array}$ \\
\hline
\end{tabular}

1) 症例数 (n): Trocar $(+): n=50, \operatorname{Trocar}(-): n=19$

2) 症例数 $(n): \operatorname{Trocar}(+): n=23, \operatorname{Trocar}(-): n=6$

3) $\chi^{2}$-test, N.S. $=$ not significant 
3) 術後の $\mathrm{Na}$ 比（図 4,5). 全症例でみると, Trocar (+) 群も Trocar (一) 群も同様の変動を示し たが，30g 以上の例に限ると, Trocar(-)群の $\mathrm{Na}$ 比 の低下がやや著明になる．Na 比の時間的経過をみる と, 術直後よりも翌日の方が低下して打り, この傾向 はとくに切除重量 $30 \mathrm{~g}$ 以上の Trocar (一) 群の場合に はっきりしている。ところが, $\mathrm{Na}$ 比は検血比とは異な り, 術後 1 週間で至涪術前值にまで回復する。なお， 切除重量 $30 \mathrm{~g}$ 未満に限った症例では, 困には示さな かったが, Trocar (+) と Trocar (-) の Na 比はそ

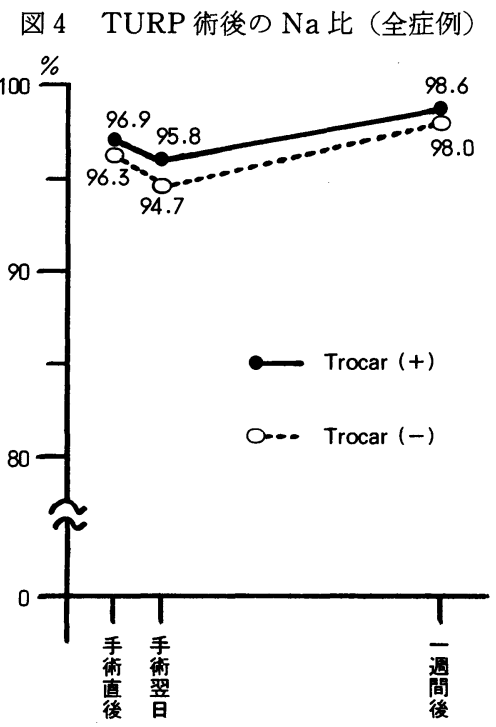

図 $5 \quad$ TURP 術後の $\mathrm{Na}$ 比（30g 以上）

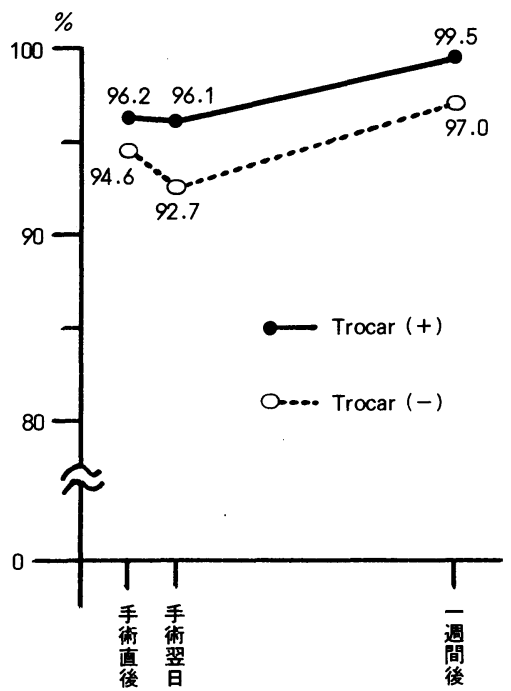

れぞれ術直後で $97.5 \%, 97.5 \%$, 翌日で $95.6 \%, 95.8 \%$, 1 週間後で $97.9 \% ， 98.6 \%$ 両群にはほとんど差がみ られなかった。

4）循環不全の頻度（表 2 ）。術中に前述の定義によ る循環不全を呈した例の頻度はTrocar（十）で, $22.0 \%$, Trocar (一) で26.3\%であった。切除重量30 $\mathrm{g}$ 以上の群では, $\operatorname{Trocar}(+) て ゙, 39.1 \%, \operatorname{Trocar}(-)$ 群で $83.3 \%$ となり, 輸血頻度とは裏腹に, $\operatorname{Trocar}(+)$ の方が循環不全発症の頻度が少ない傾向となった。

5）術中膀脱内圧の变動（図 6 ）. 術中の膀胱内圧を 測定したらちの 1 例の内圧曲線を図に示した。 TURP 開始後しばらく（約 8 分間）は持続潅流を行わず，従 来の方法によるTURPを行い，引い続いて持続潅流 を開始した。従来の TURP では内圧は $0 \sim 60 \mathrm{mmHg}$ $\left(0 \sim 81 \mathrm{cmH}_{2} \mathrm{O}\right)$ の間を上下するが，持続潅流式 TURP では0〜6mmHg $\left(0 \sim 8 \mathrm{cmH}_{2} \mathrm{O}\right)$ の間を推移した.

\section{考 案}

膀脱瘻による持続潅流式 TURP は，術中排液のた めに working elementを出し入れする必要がなく，術 中膀胼内圧の上昇が低く保たれ，また視野を見失うこ とがないなどの利点が考えられたため，われわれの施 設では，1984年秋より本法を開始した。当初は切除重 量 $30 \mathrm{~g}$ 以上と予想される症例に限って適応としていた が，前述のような利点が想像以上であったため，最近 ではほとんどの TURP は本法で执こなっている。そ こで今回は持続潅流式 TURP が, 術者の感覚ばかり ではなく, 実際に手術時間, 出血量, 潅流液吸収など の点で, 従来の方法による TURP と差があるものか 否かを検討した。

1）手術時間について（表 1). 持続潅流式 TURP は，従来の TURPに比べ，単位重量当たり 0.7 分 $/ \mathrm{g}$ と 有意 $(\mathrm{p}<0.01)$ に短縮された。これは， $30 \mathrm{~g}$ 切除する とした場合，21分の短縮となることを意味している. Holmquist $ら^{8)}$ は，持続潅流式 TURP で手術時間は約 半分に短縮されるとしているが，その一方で，従来の TURP に比へ，特に切除重量 $20 \mathrm{~g}$ 未満の場合は手術時 間に差はみられないとする報告もある9 。今回の調査 でも，20g 未満のものに限ってみると両方法に手術時 間の差はみられなかったが，これは切除重量にかかわ らず，最後の trimming に要する時間はそら変わらな いことや，手術時間のとり方にも原因があると思われ た。すなわち，小さな腺腫になると，実際の切除時間 以外の膀胖洗浄やカテーテル留置などに要する時間の 比率が多くなるため, 両者間の差が無くなるものと考 
図 6 TURP 術中の膀胼内圧. TURP 開始後吸引を始めるまでは, 従来の方法による TURPを行った。

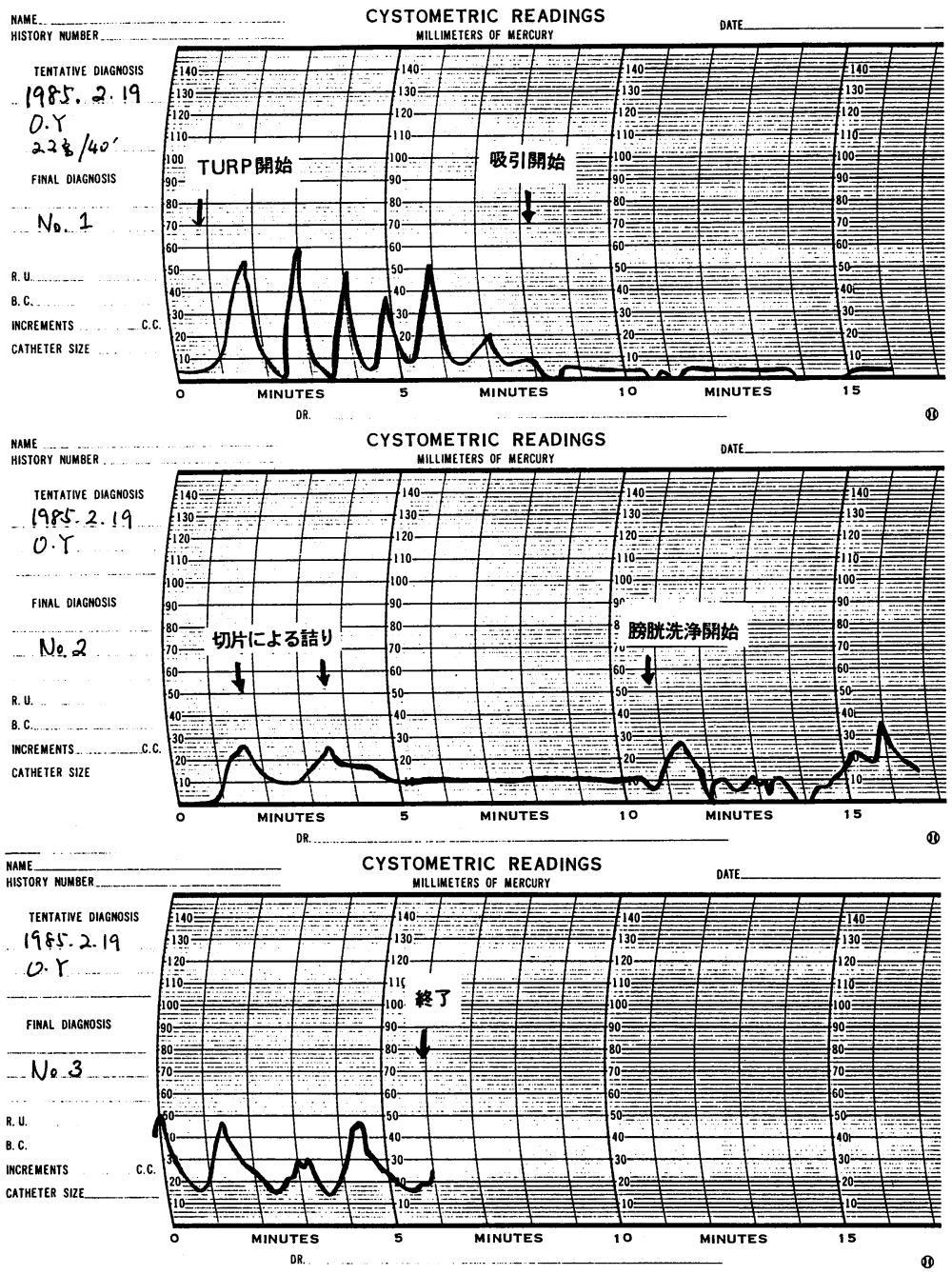

えられた。逆に $40 \mathrm{~g}$ 以上切除した場合も両法に手術時 間の差がみられなかったが，これくらいの大きさにな ると, Trocar (一) でもかなりの速度で腺腫を切除で きるためと考劣られる。

2) 出血について. 術中出血については, $\operatorname{Trocar}(+)$ の方がやや多い傾向にあるとの報告899)がある一方で, 逆に Trocar $(+)$ の方が有意に出血量が少ないとの報 告もあり ${ }^{10)}$, 必ずしも一定の評価はない.今回の検討で は，術直後の検血比は全症例でみると両者にほとんど 差はみられなかった（図 2)が，30g 以上の比較的大き な腺腫の切除の場合には, Trocar (一) に比べ手術時 間が短縮されるにもかかわらず Trocar (+) の方が検
血比が低下する傾向を示し（図 3 ）, かつ輸血頻度も Trocar (一) よりも高い（表 2) などの結果から, Trocar (+) の方が出血量が多いことが示唆された. この理由としては, Trocar (十) では視野が良好なた め, 視野を妨げない程度の出血はそのままにして切除 をすすめ得ること, 術中膀脱内圧が低いことなどがあ げられる。な挔図表には示さなかったが，切除重量30 $\mathrm{g}$ 末満のものに限ると, 術直後の Trocar $(+)$ 群の検 血比は $92.0 \%$ であったが, Trocar (一) 群では $86.7 \%$ と, $30 \mathrm{~g}$ 以上の群とは逆に Trocar (-) 群の方が低い 検血比を示し, Trocar $(+)$ 群の方が出血量が多いと はいえなかった。また輸血頻度をみても, Trocar $(+)$ 
群では切除重量 $30 \mathrm{~g}$ 未満の場合は 1 例も無かったこと から，持続潅流式 TURP に際しての出血が問題とな るとすれば， $30 \mathrm{~g}$ 以上の比較的大きな腺腫の場合であ ると言えよう。

検血比の時間的経過をみると（図 2,3 )，1 週後の 検血比は Trocar (十) 群, Trocar (-) 群共に手術直 後あるいは術翌日よりも更に低下していた。当院にお ける TURP 後の肉眼的血尿の持続はおよそ2.6日で あることから ${ }^{11}$, 術後の出血のみで 1 週間後の検血比 の低下を説明することはできない. 同様の傾向は Har-

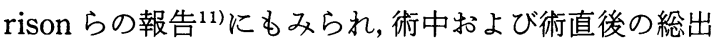
血量や，次項でも触れる血管外吸収潅流液の動態など が関係しているものと思われるが，正確な理由は不明 である。

3) 術中膀胼内圧 (図 6) と潅流液の吸収。潅流液の 高さ（水位）および膀脱または前立腺床における水圧 などと潅流液の吸収とは，深い関連があることはよく 知られている ${ }^{3122}$. 膀脱瘦による持続潅流式 TURPに 怙ける膀脱内圧は, Reuter ${ }^{7)}$ が $10 \mathrm{cmH}_{2} \mathrm{O}$ 以内(潅流液 水位 $30 \mathrm{~cm}$ ), Holmquist ${ }^{8)}$ が $10 \sim 15 \mathrm{mmHg}=14 \sim 20$ $\mathrm{cmH}_{2} \mathrm{O}$ （潅流液水位 $80 \mathrm{~cm}$ ）と報告している。 また Mosegaard $ら^{10)}$ は, $60 \mathrm{~cm}$ の潅流液水位で $12 \sim 62$ $\mathrm{cmH}_{2} \mathrm{O}$ (平均 $17 \mathrm{cmH}_{2} \mathrm{O}$ ), $40 \mathrm{~cm}$ 水位で $0 \sim 12 \mathrm{cmH}_{2} \mathrm{O}$ (平均 $8 \mathrm{cmH}_{2} \mathrm{O}$ ）となり， $40 \mathrm{~cm}$ 水位では潅流液の吸収 は Trocar (+) の方が有意に少ないが, $60 \mathrm{~cm}$ 水位で は Trocar $(+)$ \& Trocar $(-)$ も吸収量に差はなかっ たとしている。この理由として，骨盤内静脈圧と膀脱 内圧との関係をあげている.すなわち, $10 〜 15 \mathrm{cmH}_{2} \mathrm{O}$

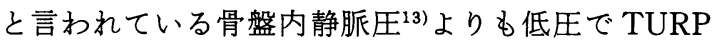
を行えば潅流液の吸収は減少すると考号られる。著者 らの測定では, 術中の膀胱内圧は Trocar $(+)$ の場合 は0 $8 \mathrm{cmH}_{2} \mathrm{O}, \operatorname{Trocar}(-)$ の場合は $0 \sim 81 \mathrm{cmH}_{2} \mathrm{O}$ と なった。従って Trocar $(+)$ の方が当然潅流液の吸収 が少ないと予想される。

な扮，当院における潅流液の水位は，手術台の高さ 及び水位の変化により，その水圧差は $50 \sim 80 \mathrm{~cm}$ とな る. この程度の水圧で切除鏡の水コックを全開にする と, 潅流液の流量が極めて多くなるため, 扣よそ半開 程度にして TURP を行っているが, $\operatorname{Trocar}(+)$ の場 合これで充分によい視野がえられた。 このように潅流 液流量を少なくしたことや, 膀胖瘦よりの吸引に軽い 陰圧をかけたことにより, 水位が50 $80 \mathrm{~cm}$ とやや高 いにもかかわらず, 術中膀胱内圧を $0 \sim 8 \mathrm{cmH}_{2} \mathrm{O}$ と低 く維持できたものと考えられる。
ところで，潅流液の吸収量の測定法については血清 $\mathrm{Na}$ 值を指標とするもの, Isotope を用いるもの, 血中 マンニトール濃度を指標とするものなどの報告がみら れるが，確立したものはない，今回著者らは術前の血 清 $\mathrm{Na}$ 值を基準とした術後の $\mathrm{Na}$ 比で潅流液吸収を推 定した。この Na 比でみると有意差はないが, Trocar （+）に比べTrocar（－）のほうが低くなる傾向にあ り, 特に $30 \mathrm{~g}$ 以上の群で著明である(図 4,5$)$.すすな ち Trocar (一) の方が潅流液の吸収も多いものと推測 された. また,この $\mathrm{Na}$ 比の時間的経過をみると(図 4 ， $5)$, 術直後に比べ術翌日の $\mathrm{Na}$ 比は更に減少してお り, 術後 1 週間後でほぼ術前値に回復している。 とこ ろで Oester $~^{\left.{ }^{14}\right)}$ は, TURP の際の潅流液の吸収は, 血 管内に $20 \%$, 膀胼周囲, 後腹膜腔に $71 \%$ が吸収される としており, Mosegaard ら ${ }^{10)}$ も血管内に吸収される潅 流液は全体の $40 \%$ 弱に過ぎないと報告している。また， レ線学的に血管外への吸収を示した報告もある15116). 高崎ら ${ }^{17)}$ は, 腹腔内に潅流液が貯留した場合は, 血管内 にのみ吸収された場合に比べ，吸収潅流液の対外排泄 が極めて遅い事を示しており，膀胼周囲及び後腹膜腔 への潅流液貯留は，血管内吸収に比へ，その対外排泄 はさらに遅れることが充分考えられる。術翌日の $\mathrm{Na}$ 比の減少は, 特に潅流液吸収が多いと思われる切除重 量 $30 \mathrm{~g}$ 以上の Trocar (-) 群で著明であることから, 吸収潅流液, 特に血管外に貯留したものが術翌日まで に多量に血管内へ引き戻されている可能性を示唆して いる.この血管外貯留潅流液の動態が, $\mathrm{Na}$ 比ばかりで なく, 先に示した術翌日の検血比の低下傾向に関係し ているものと思われる。

1 週後の $\mathrm{Na}$ 比は, 血清 $\mathrm{Na}$ 值が術前値にまでほぼ 回復していることを示していたが, Harrison ら ${ }^{11)}$ は, $\mathrm{Na}$ 值は術後48～96時間目にはすでに術前值に復して いることを報告していることから，吸収された潅流液 の大部分は，術後 2 日目には体外排泄がほぼ完了する のではないかと考えられる。

4）術中の循環不全. 今回の69例では, 一過性の高血 圧に続く低血圧, 徐脈, 意識混濁, 高度の低 $\mathrm{Na}$ 血症な どのみられる典型的な TURP 症候群は発生しなかっ た. しかし, 今回の定義によると, 切除重量 $30 \mathrm{~g}$ 以上で Trocar (十) 群に打ける循環不全の発症が $39.1 \%$ で あったのに比し，潅流液吸収の多いと考えられた Trocar (一) 群では $83.3 \%$ と高率に発症していた（表 2). ところが, 切除重量 $30 \mathrm{~g}$ 以上では, Trocar (-) 群のほうが Trocar (+) 群に比べ出血量が少ないと推 
測されることから，この循環不全は出血によるものと は考学にくい。したがって，この循環不全の発症は潅 流液の吸収と密接な因果関係にあると考えるのが妥当 であろら。

以上より，比較的大きな腺腫に対する TURP では, 従来の方法で高率にみられた軽度循環不全の徵候を, 膀胱㾇による持続潅流式 TURPを行うことでかなり 減少させることが可能であるといえよう。

\section{結語}

膀胱瘦による持続潅流式 TURP 従来の注入排液 を繰り返すTURP と比較した。

1）単位切除重量当たりの手術時間は，持続潅流式 TURPの方が有意に短縮された。

2）切除重量 $30 \mathrm{~g}$ 以上では, 持続潅流式 TURP の方 が, 従来の TURP に比し出血量が多い傾向にあるこ とが示唆されたが， $30 \mathrm{~g}$ 末満ではそのような傾向はみ られなかった。

3）術後の血清 $\mathrm{Na}$ 值の低下は, 持続潅流式 TURP の方が少なく, 潅流液の吸収が従来の TURP に比べ 少ないと考兄られたが, この傾向は, 切除重量 $30 \mathrm{~g}$ 以上 ではより一層著明であった。

4) 術中膀胱内圧は, 持続潅流式 TURP の場合 $0 \sim 6$ $\mathrm{mmHg}\left(0 \sim 8 \mathrm{cmH}_{2} \mathrm{O}\right)$ であり, 従来の TURP の場合 の0 60 $\mathrm{mmHg}\left(0 \sim 81 \mathrm{cmH}_{2} \mathrm{O}\right)$ に比へ極めて低圧に保 つことができた。

5) 術中の軽度循環不全の発症は, 持続潅流式 TURPの方が少なかった。

以上ょり, 膀胼瘻による持続潅流式 TURP は, 従来 の TURP に比べ優れた方法であり, 更に明瞭な視野 を連続的に保つことができ, 切除部および出血点の才 リエンテーションを失わずに手術を進められるなどの 利点があることから，広く勧められる方法と考兄られ た.

な⿰扌, 本論文の一部は第258回日本泌尿器科学会新潟地方 会 (1985年, 新潟) および第50回日本泌尿器科学会東部連合 総会（1985年，東京）において発表した。

\section{文献}

1）大沢哲雄, 中村 章：新潟市民病院泌尿器科に打 ける内視鏡手術。新潟市民病院医誌，5，19-24， 1984.

2) Iglesias, J.J., Sporer, A., Gellman, A.C. and Seebode, J.J. : New Igresias resectoscope with continuous irrigation, simultaneous suction and low intravesical pressure. J. Urol., 114, 929 $-933,1975$.
3) Truss, F.: Elektroresektion unter Sichtverbesserung unt Blasendruck-kontrolle. Urologe, 7 , 98-101, 1968.

4) Bergmann, M.: Die suprapubische Drainage bei der transurethralen Elektroresektion. Urologe, A, 10, 110-111, 1971.

5) Adair, E.L.: Suprapubic shunt. J. Urol., 108, 449-452, 1972.

6) McHold, D.S., Alperstein, J.B. and Valdes, J.L. : Use of suprapubic cystostomy. Urology, 1, 363-364, 1973.

7) Reuter, H.J.: Die permanente TUR unter physiologischem Blasendruck. Urologe A, 13, 114-118, 1974.

8) Holmquist, B.G., Holm, B. and Ohlin, P.: Comparative study of the Iglesias technique and the suprapubic drainage technique for transurethral resection. Brit. J. Urol., 51, 378-381, 1979.

9) Madsen, P.O. and Frimodt-M $\phi$ ller, P.C. : Transurethral prostatic resection with suprapubic trocar tedhnique. J. Urol., 132, 277 $-279,1984$.

10) Mosegaard, A. and Madsen, P.O.: Trocar cystostomy during transurethral prostatic resection. Urology, 3, 735-740, 1974.

11) Harrisonl III. R.H., Boren, S. and Robinson, J. R. : Hyponatremic shock: Another concept of the transurethral prostatic resection. J. Urol., 75, 95-110, 1956.

12) Madsen, P.O. and Naber, K.G.: The importance of the pressure in the prostatic fossa and absorption of irrigating fluid during transurethral resection of the prostate. J. Urol., 109, 446 $-452,1973$.

13) Selkurt, E.E.: Physiology. 3rd ed., p. 368, Little Brown and Co., Boston, 1971.

14) Oester, A. and Madsen, P.O.: Determination of absorption of irrigating fluid during transurethral resection of the prostate by means of radioisotopes. J. Urol., 102, 714-719, 1969.

15) Conger, K.B. and Karafin, L.: A study of irrigating medium extravasation during transurethral surgery. J. Urol., 78, 633-643, 1957.

16) Masloff, J.J., Milan, J.H. and Bunts, R.C.: Fluid and electrolyte changes associated with transurethral prostatic resection. South. Med. J., 59, 1203-1208, 1966.

17）高崎真弓, 河本昌志, 川崎 洋, 小坂義弘 : TUR に打ける低ナトリウム血症一潅流液の膀胱外溢流 と血管内吸収の比較一. 西日泌尿, 44, 197-202, 1982.

（1987年 5 月 18 日受理） 